\title{
DIREITOS FUNDAMENTAIS NO BRASIL: UMA HISTÓRIA DE INEFETIVIDADE
}

\section{FUNDAMENTAL RIGHTS IN BRAZIL: A HISTORY OF INEFECTIVENESS}

\begin{abstract}
Diego NASSIF dA Silva
Doutorando, mestre e graduado em Direito pela Universidade Estadual do Norte do Paraná (UENP). Especialista em Direito Empresarial pela Universidade Cândido Mendes (UCAM) e em Direito Público pela Universidade do Sul de Santa Catarina (UNISUL). Professor de Direito na Faculdade de Educação, Administração e Tecnologia de Ibaiti (FEATI). Ibaiti, Paraná, Brasil. diego_nassif@yahoo.com.br
\end{abstract}

VLADIMIR BREGA FILHO Pós-doutor em Direito pela Universidade de Lisboa. Doutor em Direito pela Pontifícia Universidade Católica de São Paulo. Coordenador e Professor do Programa de Mestrado em Ciência Jurídica da Universidade Estadual do Norte do Paraná. Promotor de Justiça em São Paulo. Jacarezinho, Paraná, Brasil. bregafilho@uol.com.br

\section{RESUMO}

Trata-se de estudo jurídico-científico panorâmico de revisão bibliográfica que, diante da atual comoção ética, política e institucional no Brasil, objetiva explicar a percepção de recorrente déficit de efetivação dos direitos fundamentais no país. Para tanto, relaciona direitos humanos, democracia e constitucionalismo à luz do processo histórico fazendo uso dos diferentes métodos de argumentação típicos às teorias jurídica e política que revolve. Observando coexistirem conservação e revolução das condições materiais em atenção ao ideal de universalização dos direitos, constata ser também peculiar do processo histórico-constitucional a relativização das conquistas políticas e institucionais, inclusive as da pluralista Constituição de 1988. Conclui que a efetivação dos direitos fundamentais é uma tarefa sempre a ser completada, competindo à contínua participação democrática, hoje especialmente em sede jurisdicional, dando vida à Constituição, revigorando-a em seu caráter instrumental.

Palavras-chave: Democracia; Direitos fundamentais; História; Jurisdição Constitucional.

\begin{abstract}
It is a panoramic scientific-legal study and bibliographic research that, in front of current ethical, political and institutional commotion in Brazil, aims to explain the perception of recurrent deficit of effectiveness of fundamental rights in the country. For this purpose, it connects human rights, democracy and constitutionalism in the light of the historical process making use of the different typical argumentation methods of the legal and political theories involved. Noting the coexistence of conservation and revolution of the material conditions in mind of the ideal of universalization of rights, it also finds to be peculiar in the historical-constitutional process the relativization of political and institutional conquests, including the pluralistic Brazilian Constitution of 1988. It concludes that the enforcement of fundamental rights is a task to be completed, competing to a continuous democratic participation, today specially in jurisdictional ambit, giving life to the Constitution, reinvigorating it in its instrumental character.
\end{abstract}

Keywords: Democracy; Fundamental Rights; History; Constitutional jurisdiction. 


\section{SUMÁRIO}

INTRODUÇAO; 1 HISTÓRIA E CIDADANIA: A DEMOCRACIA NA ERA DOS DIREITOS; 2 UM REGIME DE GARANTIA GERAL: A DEMOCRACIA EM MOVIMENTO; 3 DIREITOS FUNDMENTAIS NA HISTÓRIA DAS CONSTITUIÇÕES BRASILEIRAS: O PASSADO SEMPRE PRESENTE; 4 HISTÓRIA E CONSTITUIÇÃO: PASSADO E FUTURO NA CASA DOS ESPELHOS; 5 INEFETIVIDADE DOS DIREITOS FUNDAMENTAIS E JURISDIÇÃO CONSTITUCIONAL: UMA HISTÓRIA DO DEVIR; CONCLUSÃO; REFERÊNCIAS.

\section{INTRODUÇÃO}

'Direitos humanos para humanos direitos' é o slogan que muitos brasileiros adotaram ultimamente para externar sua profunda insatisfação com as respostas que o Estado tem dado acerca da inefetividade de garantias, liberdades e serviços públicos essenciais, contrastada com a propalada leniência frente aos altos índices de criminalidade no país. Diversas manifestações populares marcaram os últimos anos revelando que, apesar da relativa prosperidade econômica, isso não se refletiu suficientemente na garantia e efetivação de direitos fundamentais. Episódios de corrupção, não bastante a relativa alternância política no poder, também tem se convertido numa geral aversão ao sistema político eleitoral, desacreditando o próprio regime democrático.

Neste panorama muitas incertezas surgem: o desarranjo ético, político e institucional que se percebe hoje é fruto da redemocratização? Há que se falar de universalidade dos direitos humanos em um lugar que algo sempre falta a alguém? Relativizaram-se as conquistas da Constituição de 1988? A Constituição perdeu sua capacidade de iluminar os caminhos da sociedade brasileira, convertendo-se em um conto de fadas ou, pior, em um mero pedaço de papel? Segundo pondera Reinério Antônio Lérias, quase 200 anos e 7 constituições depois:

[...] parece que Giuseppe Tomasi di Pampeduza (1896-1957), ao escrever 0 gattopardo, em 1957, se espelhou inteiramente na história política do Brasil, pois em uma de suas passagens vaticina: 'Se queremos que tudo continue como está, é preciso que tudo mude'. Em suma, mudar para não mudar. ${ }^{1}$

\footnotetext{
${ }^{1}$ LÉRIAS, Reinéro Antonio. As constituições brasileiras: direitos fundamentais e cidadania. In: ALVES, Fernando de Brito; CAMBI, Eduardo; KLOCK, Andrea Bulgakov (Org.). Direitos fundamentais revisitados, 1. Ed., 1. reimp., Curitiba: Juruá, 2009, p. 193.
} 
Enfocando o binômio elite-massa, igualmente lembrada a frase "Façamos a revolução antes que o povo a faça" ${ }^{2}$, atribuída a Antônio Carlos Ribeiro de Andrada, sugerindo que as transformações no Brasil, mesmo com apoio popular, não tendem à satisfação de seus anseios.

Evidentemente o fenômeno social atual possui várias facetas, todas passíveis das mais diversas abordagens em diferentes profundidades. Uma delas, de índole jurídica, panorâmica e revisional bibliográfica, é a que enfoca a relação entre direitos humanos, democracia e constitucionalismo à luz da dinâmica histórica, procurando uma explicação para essa percepção de recorrente déficit de efetivação dos direitos fundamentais.

Posto esse objetivo, a fim de compreender os direitos humanos em sua relação com a democracia, parte-se da ideia de cidadania adotada por Arendt, lançando luzes sobre a aglutinação de conteúdos ao longo da histórica luta por liberdade, igualdade e fraternidade, reputados inerentes à dignidade da pessoa humana. Ato contínuo, a própria democracia deve ser colocada sob o influxo do processo histórico no intuito de revelar sua dinâmica na afirmação e concretização de direitos. Uma sucinta verificação dos direitos fundamentais nas constituições brasileiras permitirá colocar tais aspectos no contexto nacional, evidenciando a linha de desenvolvimento histórico dos direitos humanos no país. O próximo passo é adentrar na relação entre constitucionalismo e práxis democrática à luz da história, destacando o latente conflito entre os aspectos de inovação e conservação inerentes a ambos. Tendo a jurisdição constitucional papel elementar tanto na proteção da Constituição como na efetivação dos direitos fundamentais, sua análise à luz da cidadania estabelece neste âmbito as finais revelações do estudo - a que se, espera, seguem as respectivas respostas às indagações lançadas.

Com isso, por fim, espera-se contribuir para iluminar os caminhos de quem, mesmo em tempos de crise, ainda tem na efetivação dos direitos fundamentais sempre um firme propósito.

\section{HISTÓRIA E CIDADANIA: A DEMOCRACIA NA ERA DOS DIREITOS}

O direito a ter direitos, na conceituação de cidadania que nos é trazida por Arendt $^{3}$, nunca foi uma relação traçada exclusivamente entre o indivíduo e a norma. O status civitatis

\footnotetext{
${ }^{2}$ FUNDAÇÃO GETÚLIO VARGAS. Dicionário Histórico Biográfico Brasileiro pós 1930. 2. ed. Rio de Janeiro: FGV, 2001. Disponível em: <https://cpdoc.fgv.br/producao/dossies/AEraVargas1/biografias/ antonio_carlos_ribeiro_de_andrada>. Acesso em: 04 jan. 2016.
} 
DIREITOS FUNDAMENTAIS NO BRASIL: UMA HISTÓRIA DE INEFETIVIDADE

transparece a possibilidade de se adentrar pelos portões da cidade e aí ser reconhecido como um irmão, um de nós. Com efeito, embora relegada a círculos mais religiosos do que políticos ${ }^{4}$, deve-se considerar a fraternidade não só como o primeiro e mais fundamental valor da democracia, como também o elo primeiro a unir seres humanos em sociedade.

Se de um lado não se nega que as famílias, clãs, tribos, castas, tabas e todas as formas originais de associação humana se deram em razão de laços de 'consanguinidade' (reais, místicos ou míticos), de outro lado vale lembrar que na Atenas de Clístenes e Péricles só era considerado cidadão ateniense, apto a participar com vez e voz nas deliberações da demokratia, o homem cujo pai fosse ateniense e cuja mãe fosse filha de pai ateniense. Um ius sanguinis que adviria da literal fraternidade (isogonia) entre os helenos (filhos de Helen) e que determinava, por isso, a aquisição de direitos e a igualdade legal (isonomia) entre os mesmos. Em passagem do Menêxeno, Sócrates contrapõe à Constituição ateniense às que, pressupondo a desigualdade entre os homens, tornando uns servos e outros senhores, originaram tiranias e oligarquias:

Nós e os nossos, todos irmãos nascidos da mesma mãe, não nos consideramos nem escravos nem senhores uns dos outros, mas a igualdade de origem, estabelecida pela natureza, obriga-nos a buscar a igualdade de direitos políticos na lei e somente condescendermos entre nós em nome de uma única coisa, qual seja, a reputação de virtude e de sabedoria. ${ }^{5}$

Como se nota, a excepcional atribuição da qualidade de cidadão pela assembleia ateniense a quem não preenchesse os requisitos consanguíneos, não só é uma tradição cívica nos dias de hoje -e.g. atribuição do título de cidadão honorário ou a entrega das chaves da cidadecomo também marca o descolamento das relações cívicas daquelas afetas ao poder familiar.

Contribuiu para o enraizamento desta concepção no pensamento político ocidental a crença de que os homens são irmãos, filhos de um único Deus ${ }^{6}$ - colocação que marcou a crítica de Rousseau à Igreja e ao absolutismo:

Nada disse o rei Adão, nem o imperador Noé, pai dos três grandes monarcas que dividiram entre si o universo, [...]. Espero que apreciem minha moderação, pois, descendendo diretamente de um desses príncipes, e talvez do ramo mais velho,

3 LAFER, Celso. A reconstrução dos direitos humanos: a contribuição de Hannah Arendt. In: Revista Estudos Avançados. v. 11, n. 30, p. 55-65. São Paulo: Instituto de Estudos Avançados da Universidade de São Paulo, maio-ago., 1997.

4 BOBBIO, Norberto. Igualdade e liberdade. 3. ed. Carlos Nelson Coutinho (Trad.). Rio de Janeiro: Ediouro, 1997, prefácio.

5 BOBBIO, Norberto. Teoria geral da política: a filosofia política e as lições dos clássicos. Michelangelo Bovero (Org.); Daniela Beccaccia Versiani (Trad.). 5. tir. Rio de Janeiro: Campus, 2000, p. 378.

${ }^{6}$ Id. Igualdade... Op.cit., prefácio. 
quem sabe se não chegaria, depois da verificação de títulos, à conclusão de ser eu o legítimo rei do gênero humano? ${ }^{7}$

Hoje, para traçar uma ligação entre a antiga ideia de isogonia ou fraternidade e a atual noção de solidariedade, pode-se entender como fundamento desta e como forma análoga daquela um liame muito mais fundamental e nítido: a própria condição humana. Eis aí a razão primeira da isonomia e forma mais atualizada de isogonia enquanto fundamento de legitimidade e titularidade de direitos mínimos por todos os membros da 'família humana'8. Direitos esses que, para além dos formalmente ditos humanos e fundamentais, se traduzem na proclamada dignidade da pessoa humana.

Para que se tivessem reconhecidos e assegurados tais direitos é que se fez necessário fundar no reconhecimento do valor inerente à condição humana o próprio direito a ter direitos. É nessa concepção, substancial, inaugurada por Arendt, que se deve conceber a cidadania hoje. Uma cidadania que vai além do mero vínculo jurídico-formal com a política estatal e que deve não só ser reconhecido, assegurado, respeitado, mas, sobretudo, subjetivado pelo indivíduo, tornando-se parte de si, de sua autoconsciência.

Esta cidadania e a própria noção de dignidade da pessoa humana, enquanto constructos culturais basilares das sociedades ocidentais da contemporaneidade, não parecem sobreviver sem arranhões a um questionamento muito mais profundo. Todavia, como informa Bobbio, não é tanto sobre os fundamentos, mas sobre a efetivação dos direitos que se deve cuidar na Era dos Direitos $^{9}$ - momento (mais filosófico que histórico) -, em que as primeiras declarações de direitos se sobrepõem à autoridade real a obediência das leis.

Em que pese o governo das leis ter sobrepujado o governo dos homens em outras épocas, cabe destacar que o último reencontro de Direito, Política e Ética, deu-se sob o valor da dignidade da pessoa humana e à luz da Declaração Universal dos Direitos Humanos de 1948, que dispôs: "todos os seres humanos nascem livres e iguais em dignidade e em direitos. Dotados de razão e de consciência, devem agir uns para com os outros em espírito de fraternidade"10.

A retomada do paradigma do direito natural revelou não só a negação do Estado de Direito enquanto Estado Legal, mas o retorno do conceito de lei e direito inerentes a um

\footnotetext{
${ }^{7}$ ROUSSEAU, Jean-Jacques. Rousseau: vida e obra. Os pensadores. São Paulo: Abril Cultural, 1983, p. 25.

${ }^{8}$ A expressão está inclusive no preâmbulo da Declaração dos Direitos Humanos da ONU.

${ }^{9}$ BOBBIO, Norberto. A era dos direitos. Carlos Nelson Coutinho (Trad.). 13. tir. Rio de Janeiro: Campus, 1992, p. 24.

10 ORGANIZAÇÃO DAS NAÇÕES UNIDAS - ONU. Declaração universal dos direitos humanos. Paris: ONU, 1948. Disponível em <http://www.ohchr.org/EN/UDHR/Documents/UDHR_Translations/por.pdf>. Acesso em: 04 jan. 2016.
} 
conteúdo justo, a um sentido humano. A nova onda de declarações trouxe um importante movimento de normatização e proteção (judicialização) internacional de direitos, agora sob o signo não só da solidariedade, da tolerância e da paz, mas de uma fraternidade essencial.

Relembrada, pois, a dignidade humana como base isonômica, maiores explicações sobre as gerações de direitos humanos são necessárias para observar que a luta por sua positivação, proteção e efetivação pressupõem a negação ou ameaça a estas mesmas circunstâncias consideradas indispensáveis à existência digna, alçadas, por isso, à condição de direitos.

Com efeito, direitos de liberdade partiram da negação daquelas públicas e individuais surgidas de uma relação de máxima desigualdade, na qual o soberano, representado por Leviatã em Hobbes ${ }^{11}$, instaura a total e absoluta obediência de todos a uma ordem por ele estabelecida (todos são iguais perante o Leviatã). Sua queda representou a possibilidade de materialização da ilusão iluminista-contratualista do homem que, ciente e pleno de si, dispõe das suas liberdades, mantendo-se tão livre quanto antes, pois só obedeceria às leis que a si mesmo determinou ${ }^{12}$.

A conquista da liberdade, porém, não se mostrou plena, posto que a instauração da república não significou a vitória da democracia. Mesmo em Atenas mínima parte do povo era cidadã, excluída a maioria pela condição de mulher, estrangeiro, menor, velho, incapaz, escravo etc. É que, apesar de fulcrada na isogonia, surgiram critérios conseguintes: a certo ponto, exigiu-se que os cidadãos deliberantes se afastassem de qualquer atividade econômica, visando garantir a total disponibilidade e incolumidade de opinião, mas que afastava as camadas mais vulneráveis, que não podiam delegar seu sustento. Previu-se, pois, uma igualdade formal-legal, mas também uma igualdade material mínima a fim de se garantir idoneidade e legitimidade das votações. Ponto realçado na observação feita séculos depois por Rousseau:

Quereis dar consciência ao Estado? - aproximai tanto quanto possível os graus extremos, não suportai nem os opulentos nem os mendigos. Estes dois estados, naturalmente inseparáveis, são igualmente funestos ao bem comum - de um saem os fautores da tirania e de outro os tiranos. É sempre entre eles que se faz o tráfico da liberdade pública; um a compra e o outro a vende. ${ }^{13}$

Como se nota, o genebrino via na relativa igualdade material entre os cidadãos um elemento fundamental à boa Constituição, justamente para garantir a legitimidade do ordenamento jurídico resultante. Este seria o argumento pelo qual o Estado Liberal negava o

\footnotetext{
11 MORRIS, Clarence. Os grandes filósofos do direito. Reinaldo Guarany (Trad.). São Paulo: Martins Fontes, 2002. p. 114-116.

${ }^{12}$ ROUSSEAU, Jean-Jacques. Rousseau: vida e obra. Os pensadores. São Paulo: Abril Cultural, 1983, p. 37.

${ }^{13}$ Ibid., p. 66.
} 
DIREITOS FUNDAMENTAIS NO BRASIL: UMA HISTÓRIA DE INEFETIVIDADE

DIEGO NASSIF DA SILVA VLADIMIR BREGA FILHO

voto às mulheres, aos jovens, aos escravos e aos operários, já que, no mais das vezes, encontravam-se numa relação de dependência social, econômica e ideológica perante seus maridos, pais, senhores e patrões. 0 resultado foi a concentração dos bens políticos, tornando mais excluídos os que assim já se encontravam política e socialmente, retirando-lhes a chance de fazer valer na prática as liberdades e igualdades que as liberais declarações de direitos haviam thes reconhecido.

Por óbvio que tão retumbante desigualdade não se justificava, mesmo sob a alegação da utilidade comum ${ }^{14}$. Apesar de tudo, as liberdades civis ao menos eram respeitadas, dentre elas o de imprensa, sendo por via destas que os movimentos proletários deram impulso ao igualitarismo, à luta pelos direitos sociais e pela extensão dos direitos políticos. Neste ponto Bobbio observa que “a proposição normativa 'a igualdade é um bem digno de ser perseguido' não deriva sub-repticiamente, neste caso, do juízo de fato 'os homens nasceram ou são por natureza iguais', mas do juízo de valor 'a desigualdade é um mal'”'15. De fato, Hobbes e Rousseau partiram do estado de natureza tendo chegado a conclusões diferentes: Hobbes concebeu o homo homini lupos, Rousseau, o bom selvagem. Marx, porém, não parte do estado de natureza, mas chega ao igualitarismo tal qual Rousseau através daquilo que seus olhos viam: a desigualdade social do século XIX - que certamente era um grande mal a ser combatido por um Estado que tomasse a justiça distributiva como instrumento.

Tornou-se evidente a necessidade de garantir uma certa igualdade material entre todos os homens. Mas, em que grau? Se é verdade que nem mesmo os socialistas utópicos pregavam que todos os homens deviam ser iguais em tudo, também é verdade que os liberais não negavam um mínimo de igualdade dentre os mesmos homens. Dessa forma, se existia uma medida mínima de igualdade e que poderia e deveria ser materializada, foram as previstas originalmente nas declarações de direitos humanos da época - continuamente revistas à medida que novos critérios de justiça surgiram.

\footnotetext{
${ }^{14}$ No art. $1^{\circ}$ da Declaração de Direito do Homem e do Cidadão, de 1789 , consta uma ressalva pouco lembrada: "Os homens nascem e são livres e iguais em direitos. As distinções sociais só podem fundamentar-se na utilidade comum". DECLARAÇÃO de direitos do homem e do cidadão. França, 26 ago. 1789. São Paulo: USP. Disponível em: <http://www.direitoshumanos.usp.br/index.php/Documentosanteriores-\%C3\%A0-cria\%C3\%A7\%C3\%A3o-da-Sociedade-das-Na\%C3\%A7\%C3\%B5es-at\%C3\%A9-

1919/declaracao-de-direitos-do-homem-e-do-cidadao-1789.html>. Acesso em: 04 jan. 2016).

${ }^{15}$ BOBBIO, Norberto. Igualdade e liberdade. 3. ed. Carlos Nelson Coutinho (Trad.). Rio de Janeiro: Ediouro, 1997, p. 39.
} 
Como defende Bobbio $^{16}$, embora haja a diversidade de posicionamento entre liberalismo (individualista, conflitualista e pluralista) e igualitarismo (generalizante, harmônico e monista), a mesma não vem a constituir empecilho a uma proposta de síntese teórica e solução prática entre liberdade e igualdade, na medida em que esses valores fundamentais à democracia são, além de não-antinômicos necessariamente, parcialmente complementares, como se exige tanto na tese quanto na prática dos governos democráticos.

Disso, a questão que resta a resolver é: se a desigualdade é um mal, até que ponto a igualdade é um bem? Como afirma Comparato, "é o princípio da solidariedade que constitui o fecho da abóbada de todo o sistema de direitos humanos" ${ }^{17}$, de forma que hoje se há um Estado que busca harmonizar liberdade e igualdade este é o Estado Democrático de Direito, cuja gênese deu-se na soma das dimensões de direitos (liberdades civis e públicas, direitos sociais e de solidariedade) visando estabelecer entre eles o equilíbrio ideal com base na dignidade inerente à condição humana, assim compreendida em toda a sua diversidade.

\section{UM REGIME DE GARANTIA GERAL: A DEMOCRACIA EM MOVIMENTO}

Segundo Bonavides, a democracia seria o regime de garantia geral para a realização dos direitos fundamentais do homem, sendo ela mesma um direito de quarta dimensão e os direitos das demais dimensões suas infraestruturas, formando "a pirâmide cujo ápice é o direito à democracia” ${ }^{18}$. José Afonso, por sua vez, afirma que a democracia não seria por si um valor-fim, mas "meio e instrumento de realização de valores essenciais de convivência humana, que se traduzem basicamente nos direitos humanos" ${ }^{19}$.

Comparato consigna que da Declaração Universal de 1948 extrai-se que a democracia é o "único regime político compatível com o pleno respeito aos direitos humanos" (arts. 21 e 29, item 2), de modo que “o regime democrático já não é, pois, uma opção política entre muitas

\footnotetext{
${ }^{16}$ BOBBIO, Norberto. Igualdade e liberdade. 3. ed. Carlos Nelson Coutinho (Trad.). Rio de Janeiro: Ediouro, 1997. p. 40-43.

${ }^{17}$ COMPARATO, Fábio Konder. A afirmação histórica dos direitos humanos. 3. ed. rev. ampl. 2. tir. São Paulo: Saraiva, 2004. p. 333.

${ }^{18}$ BONAVIDES, Paulo. Curso de direito constitucional. 10. ed. rev. atual. São Paulo: Malheiros, 2000. p. 525.

19 SILVA, José Afonso da. Curso de direito constitucional positivo. 17. ed. rev. atual. São Paulo: Malheiros, 2000. p. 129.
} 
DIREITOS FUNDAMENTAIS NO BRASIL: UMA HISTÓRIA DE INEFETIVIDADE

DIEGO NASSIF DA SILVA VLADIMIR BREGA FILHO

outras, mas a única solução legítima para a organização do Estado” ${ }^{20}$, pelo que acrescenta, com base no artigo 25 do Pacto Internacional dos Direitos Civis e Políticos, que:

[...] as constituições nacionais que não reconhecem, hoje, as instituições da democracia direita (plebiscito, referendo, iniciativa popular, orçamento participativo) são não apenas ilegítimas como na verdade contrárias à ordem internacional dos direitos humanos. ${ }^{21}$

Neste diapasão, de relevo é a lição de Eduardo Cambi:

A pessoa não é apenas um agente da liberdade, mas o resultado de uma confluência de fatores, especialmente de condições materiais mínimas, necessárias para que possa atingir o seu máximo potencial. 0 discurso da efetivação dos direitos fundamentais e da busca de uma democracia realmente efetiva encontra no conceito de mínimo existencial um dos argumentos mais importantes para a promoção da dignidade da pessoa humana. ${ }^{22}$

O autor ainda destaca julgado da Corte Interamericana de Direitos Humanos:

A vida humana não é apenas subsistência. Ela é uma existência que se dignifica em situações onde um indivíduo pode atingir seu máximo potencial. A plena realização dessa ideia é o objetivo de uma visão enriquecida dos direitos fundamentais, mas também de uma democracia realmente efetiva. ${ }^{23}$

Portanto, em regime de garantia geral, a democracia é princípio que parece constituir o próprio substrato social e institucional sobre o qual se é unicamente possível conceber a efetivação dos direitos humanos e fundamentais ${ }^{24}$. Ora, nem a democracia é um fim em si, nem os direitos o são. A maior finalidade da organização política (e jurídica dele decorrente) é o bem comum de seus membros e que João XXIII definiu como o "conjunto de todas as condições de vida social que consintam e favoreçam o desenvolvimento integral da pessoa humana" ${ }^{25}$. Tem-

${ }^{20}$ COMPARATO, Fábio Konder. A afirmação histórica dos direitos humanos. 3. ed. rev. ampl. 2. tir. São Paulo: Saraiva, 2004, p. 231.

${ }^{21}$ Ibid. p. 317.

${ }^{22}$ CAMBI, Eduardo. Neoconstitucionalismo e neoprocessualismo: direitos fundamentais, políticas públicas e protagonismo judiciário. São Paulo: Revista dos Tribunais, 2010, p. 392.

${ }^{23}$ Ibid., loc. cit.

${ }^{24}$ Embora em muitos pontos os direitos humanos possam ter o mesmo conteúdo dos direitos fundamentais, os aqueles são mais amplos e imprecisos, enquanto que estes possuem um conteúdo mais restrito e preciso, pois estão limitados aos direitos reconhecidos pelo direito positivo de determinado povo. Assim, o que essencialmente difere o direito fundamental do direito humano fundamental não é tanto sua substância, seu conteúdo, mas a precisão com que é descrito e se está nacionalmente ou internacionalmente reconhecido ou positivado.

25 JOÃO XXIII. Encíclica pacem in terris. Roma: Vaticano, 11 abr. 1963, Item 58. Disponível em: $<$ http://w2.vatican.va/content/johnxxiii/pt/encyclicals/documents/hf_jxxiii_enc_11041963_pacem.html\#_ftn34>. Acesso em: 04 jan. 2016. 
DIREITOS FUNDAMENTAIS NO BRASIL: UMA HISTÓRIA DE INEFETIVIDADE

DIEGO NASSIF DA SILVA VLADIMIR BREGA FILHO

se, pois, conteúdo (dignidade-fundamento, cidadania-condição e direitos-circunstância), forma (democracia) e fim (bem comum ou mínimo existencial), restando-nos colocá-los em movimento.

Considerando as diversas realidades humanas e sociais, Bobbio indagou se seria possível a sobrevivência de um Estado democrático em uma sociedade não democrática ${ }^{26}$. De maneira genérica, isto leva a questionar se existem pressupostos à democracia.

Se tomada a democracia unicamente como democracia política, como parece fazer Ferreira Filho, há que se convir que "as circunstâncias e a conjuntura evidentemente condicionam o tipo e o grau de democracia que é possível a cada momento" ${ }^{27}$, não existindo um modelo imutável e universal de regime democrático. Ou seja, assim como qualquer outra forma de governo, a democracia possível em uma dada realidade depende de questões sociais, econômicas, culturais, institucionais, dentre outras, tornando-se, por isso, verdadeiros requisitos, pressupostos ou condições para o seu implemento.

Os que se colocam opostos a esta opinião tomam a democracia em termos mais amplos, estando dentre eles José Afonso da Silva, que afirma:

[...] em verdade a tese inverte o problema, transformando, em pressupostos da democracia, situações que se devem ter como parte de seus objetivos: educação, nível de cultura, desenvolvimento, que envolva a melhoria de vida, aperfeiçoamento pessoal, enfim, tudo se amalgama com os direitos sociais, cuja realização cumpre ser garantida pelo regime democrático. Não são pressupostos desta, mas objetivos. Só numa democracia pode o povo exigi-los e alcançá-los.

[...]. Finalmente, os que reclamam que a democracia nunca fora realizada em sua pureza em lugar algum concebem-na como um conceito estático, absoluto, como algo que há que instaurar-se de uma vez e assim perdurar para sempre. Não percebem que ela é um processo, e um processo dialético que vai rompendo os contrários, as antíteses, para, a cada etapa da evolução, incorporar conteúdo novo, enriquecendo novos valores. Como tal, ela nunca se realiza inteiramente, pois, como qualquer vetor que aponta valores, a cada nova conquista feita, abrem-se outras perspectivas, descortinam-se novos horizontes ao aperfeiçoamento humano, a serem atingidos. ${ }^{28}$

\footnotetext{
Ver também: Id. Encíclica mater et magistra. Roma: Vaticano, 15 maio 1961, item 65. Disponível em: <http://w2.vatican.va/content/john-xxiii/pt/encyclicals/documents/hf_jxxiii_enc_15051961_mater. html>. Acesso em: 04 jan. 2016.

${ }^{26}$ BOBBIO, Norberto. 0 futuro da democracia. 8. ed. rev. ampl. Marco Aurélio Nogueira (Trad.). São Paulo: Paz e Terra, 2002, p. 68.

27 FERREIRA FILHO, Manoel Gonçalves. A democracia possível. São Paulo: Saraiva, 1972, p. 37. Ver também: FERREIRA FILHO, Manoel Gonçalves. Democracia no limiar do século XXI. São Paulo: Saraiva, 2001, prefácio.

28 SILVA, José Afonso da. Curso de direito constitucional positivo. 17. ed. rev. atual. São Paulo: Malheiros, 2000. p. 130-133.
} 
DIREITOS FUNDAMENTAIS NO BRASIL: UMA HISTÓRIA DE INEFETIVIDADE

DIEGO NASSIF DA SILVA VLADIMIR BREGA FILHO

Ambas as posições parecem corretas ao mesmo tempo que opostas. A razão desta ambivalência parece simples: são doutrinas mais complementares do que divergentes. $E$ isto fica claro quando Macpherson, em outro contexto, debruçou-se sobre a investigação de meios para impulsionar a democracia participativa, vindo ele a deparar-se com a seguinte verificação:

[...] não podemos conseguir mais participação democrática sem uma mudança prévia da desigualdade social e sua consciência, mas não podemos conseguir as mudanças da desigualdade social e na consciência sem um aumento antes da participação democrática. ${ }^{29}$

Macpherson, a seu modo, atingiu o mesmo paradoxo entre os discursos de Ferreira Filho e José Afonso: o primeiro observa condições materiais para a democracia e o segundo afirma serem improváveis tais pressupostos sem a prévia existência de uma democracia (política e social). Segundo Macpherson, um círculo vicioso ${ }^{30}$ no qual não se poderia esperar a mudança em um dos termos sem pressupor a mudança no outro, vindo a concluir:

Desse modo, devemos procurar saídas em outra parte do círculo, isto é, procurar mudanças já visíveis ou em perspectiva [...]. Se verificarmos mudanças que sejam não só já perceptíveis mas que sejam, atribuíveis a forças ou circunstâncias que tenham probabilidade de operar com efeito cumulativo, então podemos ter alguma esperança de uma ruptura. E se as mudanças forem de natureza a incentivar mudanças recíprocas nos demais fatores, tanto melhor. ${ }^{31}$

Os dois requisitos de ordem material apontados pelo canadense (maior igualdade social e consciência política) são uma colocação genérica daquilo que Ferreira Filho pôs como pressupostos da democracia; já o movimento recíproco entre estes pressupostos e a maior participação democrática tem clara correspondência com o processo dialético apontado por José Afonso. Reforça-se, pois, a ideia de que democracia exige participação do povo em termos mais amplos do que a mera participação no processo eleitoral.

Ou seja, não há que se falar necessariamente em pressupostos para a democracia, pois a democracia só existe em movimento, que só é obtido com a contínua participação popular,

${ }^{29}$ MACPHERSON, Crawford Brough. A democracia liberal: origens e evolução. Nathanael C. Caixeiro (Trad.). Rio de Janeiro: Zahar, 1978. p. 103.

${ }^{30}$ Nas suas palavras: "Ora, se essas duas mudanças na sociedade [...] são pré-requisitos da democracia participativa, parece termos caído num círculo vicioso. Porque é improvável que qualquer desses dois requisitos sejam satisfeitos sem uma participação democrática muito maior do que agora. [...]. Daí o círculo vicioso: não podemos conseguir mais participação democrática sem uma mudança prévia da desigualdade social e sua consciência, mas não podemos conseguir as mudanças da desigualdade social e na consciência sem um aumento antes da participação democrática." (Ibid., loc. cit.).

31 MACPHERSON, Crawford Brough. A democracia liberal: origens e evolução. Nathanael C. Caixeiro (Trad.). Rio de Janeiro: Zahar, 1978. p. 104. 
tanto na esfera propriamente política quanto na esfera social, sendo certo que, de maneira ideal, ambos, democracia política e democracia social, devem evoluir sem grandes disparidades, a fim de que se garanta a solidez e o equilíbrio no desenrolar do processo democrático.

Em síntese, as circunstâncias existenciais mínimas necessárias para a garantia e efetivação da dignidade inerente à condição humana ${ }^{32}$ hoje fazem parte do próprio conceito de democracia, seja como seu pressuposto, seja como seu fim. De um modo ou de outro, sua força motriz encontra-se na maior ou menor participação popular nos âmbitos social e institucional.

Deve-se considerar, porém, que a maior ou menor participação popular por si não garante efeitos cíclicos na relação social-institucional, pois, assim como a sociedade pode contribuir para o aperfeiçoamento das instituições políticas, há circunstâncias que, reverberando na população, podem influir anticiclicamente sobre um legado democrático institucional. 0 estudo e controle destas influências no intuito de conferir perpetuidade ao sistema de governo inspira a humanidade há milênios e sua escola é a própria história. As constituições de cada povo e sociedade são, assim, experiências postas à prova para o fim de verificar sua perfeição avaliação esta que se faz possível inclusive a partir do propósito assumido pelos estados democráticos de direito de efetivar internamente os direitos humanos.

\section{DIREITOS FUNDAMENTAIS NA HISTÓRIA DAS CONSTITUIÇÕES BRASILEIRAS: O PASSADO SEMPRE PRESENTE}

A marca indelével da Era dos Direitos são suas declarações de direitos. O artigo XVI da Declaração dos Direitos do Homem e do Cidadão 33 já informava que "a sociedade em que não esteja assegurada a garantia dos direitos nem estabelecida a separação dos poderes não tem Constituição" reforçando que, a reboque dos direitos humanos, presente o constitucionalismo.

A Constituição estadunidense não continha de início uma declaração de direitos fundamentais. Tal só foi introduzida por ser condição imposta por alguns dos estados independentes à adesão ao Estado Federal. A Constituição francesa de 1791 trouxe formas de controle do poder estatal, mas coube à Constituição de 1793 uma melhor regulamentação dos

\footnotetext{
${ }^{32}$ CAMBI, Eduardo. Neoconstitucionalismo e neoprocessualismo: direitos fundamentais, políticas públicas e protagonismo judiciário. São Paulo: Revista dos Tribunais, 2010. p. 391.

33 DECLARAÇÃO de direitos do homem e do cidadão. França, 26 ago. 1789. São Paulo: USP.Disponível em: <http://www.direitoshumanos.usp.br/index.php/Documentos-anteriores-\%C3\%A0-

cria\%C3\%A7\%C3\%A3o-da-Sociedade-das-Na\%C3\%A7\%C3\%B5es-at\%C3\%A9-1919/declaracao-de-direitos-dohomem-e-do-cidadao-1789.html>. Acesso em: 04 jan. 2016.
} 
direitos fundamentais, reconhecendo-os no seu próprio texto. Esta internalização dos direitos humanos, convertendo-os em direitos fundamentais ocorreu também na Espanha em 1812, em Portugal em 1922 e na Bélgica em 1931.

Isso permitiu as bases para a construção de um sistema internacional para controle dos direitos humanos. A Carta Geral das Nações Unidas, de 1945, estabeleceu o comprometimento e a responsabilidade dos signatários para com os objetivos da ONU, dentre os quais o respeito e promoção aos direitos humanos bem como a proclamação de uma Declaração Universal dos Direitos do Homem, que em 1948 definiu o rol de direitos garantidos. Embora sem força jurídica obrigatória, tal instrumento iniciou uma nova onda de declarações de direitos e um processo de judicialização internacional, reverberando sobre as constituições dos países signatários.

As interferências no direito positivo interno entre os países e com os organismos da comunidade internacional não é nova e destaca a influência do processo histórico sobre o fenômeno constitucional. As Constituições do Brasil sempre tiveram declarações de direitos, sendo que a pseudo liberal Carta do Império, de 1824, reconheceu alguns direitos individuais no art. 179, sob o título 'Garantia dos direitos civis e políticos dos cidadãos brasileiros', onde previu direitos sociais a prestações positivas, como o direito à educação primária gratuita. Mas nem por estes avanços a Carta deixou de ser instrumento absolutista. Não previu remédios básicos, como o habeas corpus, revelando historicamente um baixíssimo grau de eficácia jurídica e social.

A Constituição de 1891, inspirada pelos ideais republicanos e pelo liberalismo, deu grande importância aos direitos individuais, prevendo, no art. 72, uma 'Declaração de Direitos', dentre os quais meios para sua garantia. Avançou ao estendê-los também aos estrangeiros (art. $72, \$ 2^{\circ}$ ) e a reconhecer que não os mencionava de maneira exaustiva (art.78), mas regrediu ao esquecer os direitos sociais. De novo a Constituição distanciou-se da realidade:

Entre a Constituição jurídica e a Constituição sociológica havia enorme distância; nesse espaço se cavara também o fosso social das oligarquias e se descera ao precipício político do sufrágio manipulado, que fazia a inautenticidade da participação do cidadão no ato soberano de eleição dos corpos representativos. ${ }^{34}$

A Constituição de 1934 inaugurou o Estado Social no Brasil, determinando que o direito de propriedade não poderia ser exercido contra o interesse social ou coletivo (art. 113, inc.17) bem como que a ordem econômica deveria ser organizada conforme os princípios da justiça e as necessidades da vida nacional, de modo que possibilitasse a todos existência digna (art. 115).

\footnotetext{
${ }^{34}$ BONAVIDES, Paulo; ANDRADE, Paes de. História constitucional do Brasil. 3. ed., Rio de Janeiro: Paz e terra, 1991, p. 252.
} 
Inovou também na defesa dos direitos com o mandado de segurança. Sua curta vida, porém, impediu the de ter real efetividade, não deixando nem por isso de ser um marco importante.

A 'Polaca', de 1937, resultado das aspirações totalitárias de Vargas, restringiu os direitos e garantias individuais. Foram vários os desrespeitos aos direitos fundamentais, sintetizados por Ylves José de Miranda Guimarães:

A carta de 1937 restringiu direitos e garantias individuais, abolindo o mandado de segurança e alijando os princípio de legalidade e irretroatividade da lei, instituiu a censura prévia e a pena de morte em casos expressamente especificados, inclusive para a subversão da ordem política e social por meios violentos e para o homicídio cometido por motivo fútil e com extremos de perversidade. ${ }^{35}$

Previa-se um plebiscito para a sua legitimação e a eleição do Congresso Nacional, ambos jamais realizados. Assim, o país ficou sem Constituição, sem partidos políticos, sem imprensa livre, e embora o art. 122 reconhecesse direitos individuais, estes não tiveram efetividade, pois com a ditadura houve concentração de poderes nas mãos do Presidente da República, que governava através de decretos-leis e de leis constitucionais.

$\mathrm{Na}$ Constituição de 1946 ressurgiram os direitos fundamentais nos capítulos relativos à 'Nacionalidade e a Cidadania' e aos ‘Direitos e Garantias Individuais' (arts. 129 a 144). Foram abolidas as penas de morte e perpétua, restaurados os institutos do habeas corpus, do mandado de segurança e da ação popular, bem como, a integralidade dos princípios da legalidade e irretroatividade da lei. No campo dos direitos sociais, instituiu a participação obrigatória e direta do trabalhador nos lucros da empresa, o repouso semanal remunerado e reconheceu o direito de greve. Ademais, instituiu que a lei não poderia excluir da apreciação do Poder Judiciário qualquer lesão de direito individual, estabelecendo um Estado de direito com harmonia entre os poderes.

Com o golpe militar de 1964, a Constituição de 1946 foi formalmente mantida, sofrendo profunda interferência, inclusive no campo dos direitos fundamentais, por meio de atos institucionais, como o $\mathrm{n}^{\circ} 1$, que suspendeu as garantias constitucionais ou legais da vitaliciedade e estabilidade dos juízes, permitiu a cassação dos mandados legislativos e a suspensão dos direitos políticos. $O$ ato institucional $n^{\circ} 2$ extinguiu os partidos políticos e deu poderes ao Presidente da República para decretar o recesso do Congresso Nacional. 0 ato institucional $n^{\circ} 4$ convocou o Congresso Nacional para discutir e votar um novo texto constitucional, cuja redação

35 GUIMARÃES, Ylves José de Miranda. Comentários à constituição: direitos e garantias individuais e coletivas. Rio de Janeiro: Forense, 1989, p. 2. 
final não foi outorgada por representantes populares, mas homologada por um Congresso desfalcado por cassações de mandato da oposição ao governo militar, sendo, portanto, facilmente aprovada a proposta do Poder Executivo.

A Carta de 1967 previa direitos e garantias individuais (art. 150) e direitos sociais (art. 158), porém o ato institucional $n^{\circ} 5$, de 1968, além de restaurar os atos institucionais anteriores, suspendeu o habeas corpus e concedeu total arbítrio ao Presidente da República para a decretação do estado de sítio. A emenda constitucional $n^{\circ} 1$, de 1969 , produziu modificações, mas sem impacto substancial no que se refere aos direitos fundamentais.

A Constituição de 1988, focada na redemocratização do Brasil, ampliou o rol expresso, mas não exaustivo, de direitos fundamentais atribuindo-lhes eficácia imediata bem como posição prestigiada na edificação do texto constitucional - tratou deles no Título II, logo após aquele relativo aos princípios fundamentais e antes mesmo da própria organização do Estado. Refletindo a melhor estruturação de um sistema global de proteção dos direitos humanos com a adoção de mecanismos aptos à sua justiciabilidade, a Constituição 'Cidadã' reconheceu a existência de direitos fundamentais decorrentes de tratados internacionais. Na sua curta vida, paradoxalmente o mais longo período democrático do país, já conta com cerca de noventa emendas, revelando que nem o mais pluralista, democrático e dúctil diploma constitucional que já produzimos é capaz de se descolar do homem coevo.

Resta claro que a positivação dos direitos humanos no ordenamento jurídico nacional, embora indispensável, não é garantia de efetivação, pois 200 anos e 7 constituições depois o Brasil continua a ser um país com contradições e desigualdades tão grandes quanto sua diversidade e dimensão. Diante disso, seriam as constituições ainda hoje algo que se pretender por e ficar no horizonte, um marco final, a derradeira tentativa de concretizar o sonho do automaton político, a Constituição perfeita? E, diante do seu eventual insucesso, substituí-la por outra e outra? Para melhor espiar uma resposta ao questionamento, entremostra-se proveitoso enfocar a dinâmica das implicações entre processo constitucional e processo histórico. 


\section{HISTÓRIA E CONSTITUIÇÃO: PASSADO E FUTURO NA CASA DOS ESPELHOS}

$\mathrm{Na}$ epígrafe do seu artigo ' $\mathrm{O}$ processo penal e os direitos humanos sob os grilhões do nosso passado inquisitorial', Reinéro Antônio Lérias, utiliza-se da seguinte citação de M.Davison Post-Uncle Abner:

São os mortos que governam. Veja homem, veja como eles impõem sua vontade sobre nós. Quem faz as leis? Os mortos! Quem faz os costumes a que obedecemos e que formam e moldam as nossas vidas? Os mortos![...] Se traça uma linha o agrimensor começa em algum ponto estabelecido pelos mortos; e se alguém apela para a lei numa questão, o juiz examina o passado em seus livros até descobrir como os mortos a resolveram e segue a mesma norma.[...]. ${ }^{36}$

Reinéro pondera que a colocação “nos leva, pelo menos, a três indagações. São os mortos que delimitam a vida dos vivos? Ou, são os vivos que dão vida aos mortos? Ou, as duas coisas ao mesmo tempo?” ${ }^{37}$. Em ‘Ética, moral, ciência e direitos humanos' o autor considera:

Consoante a hipótese de Nelson Levy em trabalho recente, "[...] a continuidade de cada tempo histórico transcorre sob a ilusão da infinitude: cada época resiste à mudança enquanto os seus valores fundamentais estiverem sendo avaliados como os melhores para o grupo e até para a humanidade". (2004, p. 57). Todavia, esta mesma ilusão da infinitude destes valores e normas, acaba por dar lugar aos desejos de mudança, na medida em que são açodados por descrenças de toda ordem. Se não como se explicaria as mudanças aludidas? Conquanto não se processem um total rompimento com a ordem anterior [...] um paradigma cultural acaba com o tempo entrando em crise e com ela cirando condições para a sua [própria] transcendência. ${ }^{38}$

A relação entre história e Constituição não é nova, remontando aos primeiros escritos filosóficos, quando se buscava a forma de governo perfeita, aquela que, uma vez instituída, perpetuaria para a eternidade.

No prólogo do livro 'História e Constituição' de Zagrebelsky, Carbonell relata que a Constituição de nosso tempo convive com o passado, renunciando a sua repetição em certos casos (como os totalitarismos), mas, sobretudo, constitui uma aspiração para o futuro - como

${ }^{36}$ LÉRIAS, Reinéro Antonio. O processo penal e os direitos humanos sob os grilhões de nosso passado inquisitorial. Argumenta: Revista do Programa de Mestrado em Ciência Jurídica, da Universidade Estadual do Norte do Paraná - UENP, n. 16, jan./jul., Jacarezinho: UENP, 2012, p. 13.

37 Ibid., loc. cit.

${ }^{38}$ Id. Ética, moral, ciência e direitos humanos. In: Argumenta: Revista do Programa de Mestrado em Ciência Jurídica, da Universidade Estadual do Norte do Paraná - UENP, n. 7, jan./jul., Jacarezinho: UENP, 2008, p.113. 
DIREITOS FUNDAMENTAIS NO BRASIL: UMA HISTÓRIA DE INEFETIVIDADE

DIEGO NASSIF DA SILVA VLADIMIR BREGA FILHO

uma 'utopia concreta' conforme Habermas ou uma 'carta de navegação' na proposta de Carlos S. Nino ${ }^{39}$. Assim, "se a Constituição se apresenta como uma excisão entre o passado e o presente, como um ponto de inflexão fundacional" ou se entende como um seguimento das "leis naturais da história', expressão dos costumes sociais e do 'ser' do 'organismo social', "estaremos diante de um falseamento da realidade. Um sistema constitucional não é nem pode ser, na prática, somente revolução ou somente conservação" ${ }^{40}$ :

[...] A Constituição da Revolução olhava somente para frente. A Constituição da Conservação olhava somente para trás. As constituições do nosso tempo olham para o futuro tendo firme o passado, diga-se, o patrimônio de experiência histórico-constitucional que querem salvaguardar e enriquecer. Inclusive se poderia dizer: passado e futuro se ligam em uma única linha e, tal como os valores do passado orientam a busca do futuro, assim também as exigências do futuro obrigam a uma contínua observação do patrimônio constitucional que vem do passado e, portanto, uma incessante redefinição dos princípios de convivência constitucional. A "história" constitucional não é um passado inerte, senão a contínua reelaboração das raízes constitucionais do ordenamento que nos é imposta no presente pelas exigências constitucionais do futuro. ${ }^{41}$

Sob a premissa de um poder constituinte soberano o positivismo viu a Constituição como algo dado, contrapondo à vontade racional o irracional movimento histórico-político espontâneo. Já as revolucionárias declarações de direitos marcaram o universalismo atemporal e absoluto oriundo da apreensão racional dos 'princípios imortais' da natureza, demarcadoras do determinismo naturalista da história. Sob este ponto de vista, sendo história constitucional e poder constituinte incompatíveis, a primeira restou condenada.

Diante disso, considera-se duas possibilidades: ou ordem constitucional se instaura de uma vez para sempre, pois instauradora da ordem perfeita e imutável, e a revolução termina; ou

${ }^{39}$ ZAGREBELSKY, Gustavo. Historia y constitución. Miguel Carbonell (Trad.). Torino: Minima Trotta, 1996, p. 11.

${ }^{40}$ ZAGREBELSKY, Gustavo. Historia y constitución. Miguel Carbonell (Trad.). Torino: Minima Trotta, 1996, p. 11. Tradução nossa: “[...]. Si la constitución se apresenta como una escisión entre el pasado y el presente, como un punto de inflexión fundacional, [...], o bien si la entende como un seguimento de las 'leyes naturales de la historia', expressión de las costumbres sociales y del 'ser' del 'organismo social' [...], estaremos ante un falsemiento de la realidade. Un sistema constitucional no es ni puede ser, em la práctica, solamente revolución o solamente conservación [...]".

${ }^{41}$ Ibid., 90-91. Tradução nossa: “[...]. La constitución de la Revolución miraba solamente hacia adelante. La constitución de la Conservación miraba solamente hacia atrás. Las constituiciones de nuestro tempo miran al futuro teniendo firme el passado, es decir, el patrimônio de experiência histórico-constitucional que quieren salvaguardar y enriquecer. Incluso se podría decir: passado y futuro se ligan em una única línea y, al igual que los valores del passado orientan la búsqueda del futuro, así también las exigencias del futuro obligan a una continua puntualización del patrimônio constitucional que viene del passado y por tanto a una incessante redefinición de los princípios de la convivencia constitucional. La 'historia' constitucional no es un passado inerte sino la continua reelaboración de las raíces constitucionales del ordenamento que nos es impuesta en el presente por las exigencias constitucionales del futuro." 


\section{(R)

DIREITOS FUNDAMENTAIS NO BRASIL: UMA HISTÓRIA DE INEFETIVIDADE

DIEGO NASSIF DA SILVA VLADIMIR BREGA FILHO

o direto se reconstrói a cada nova geração, tornando-se retrato fiel das concepções políticas - 'a terra pertence aos vivos' diz Jefferson a Madison ${ }^{42}$. Por Zagrebelsky, nenhum dos extremos prevaleceu, vigorando a difícil síntese entre as exigências de conservação e renovação:

[...]. Os procedimentos especiais para a reforma constitucional apresentam uma dupla face, uma que olha a mudança e outra que o faz com a conservação: uma duplicidade que historicamente está destinada a suscitar temor ou impaciência dos partidos conservadores e renovadores. ${ }^{43}$

Madison entendia que entre a geração constituinte e as que the sucediam havia uma relação de respeito e perpetuação tal como a existente entre os pais (fundadores) e os filhos. Difunde-se também a excepcionalidade do 'momento constituinte'. Com isto, havia a necessidade de alimentar um mito (fundador) constituinte por meio de uma hierarquia entre as gerações, a qual nos alcança até hoje. Assim, percebe-se que, quando se quer mudar a Constituição, com frequência se começa a destruir os méritos dessa geração ${ }^{44}$.

Esgotada sua primeira função de aceleração histórica, a Constituição converte-se em instrumento de conservação. Se a rigidez total criava o risco de colapso total ao mínimo esforço, a flexibilidade absoluta não se sustentava. Desta forma, previu-se uma parte autenticamente constitucional uma parte instrumental e, por isso, adaptável aos tempos ${ }^{45}$.

Os liberais revolucionários, crendo que a autoridade e o direito estão nas mãos dos homens, que a si delegam o poder de determinar o curso da história constitucional, viram que o caráter essencial de uma ciência positiva da Constituição seria seu vínculo com a vontade constituinte. Prossegue o autor:

[...] toda a ideologia constitucional da revolução, desde o ponto de vista das "forças constituintes", está contida em sua posição ahistórica ou anti-histórica. Uma visão da Constituição sem passado, já que nasce de uma fratura, e sem

\footnotetext{
42 UNIVERSITY OF GRONINGEN. American History: from revolution to reconstruction and beyond - The Letters of Thomas Jefferson 1743-1826: to James Madison Paris, Sep. 6, 1789. Disponível em: <http://www.let.rug.nl/usa/presidents/thomas-jefferson/letters-of-thomas-jefferson/jefl81.php>. Acesso em: 04 jan. 2016.

${ }^{43}$ ZAGREBELSKY, Gustavo. Historia y constitución. Miguel Carbonell (Trad.). Torino: Minima Trotta, 1996, p. 44. Tradução nossa: “[...]. Los procedimentos especiales para la reforma constitucional presentan una doble cara, una que mira al cambio y otra que lo hace a la conservación: una duplicidad que históricamente está destinada a suscitar el temor o la impeciencia de los partidos conservadores y renovadores."

${ }^{44}$ Ibid., p. 44-46.

${ }^{45}$ Ibid., p. 47-49.
} 
DIREITOS FUNDAMENTAIS NO BRASIL: UMA HISTÓRIA DE INEFETIVIDADE

DIEGO NASSIF DA SILVA VLADIMIR BREGA FILHO

futuro, ou melhor, com um futuro todo concentrado ou contraído na aceleração representada pelo ato constituinte. $\left[\ldots . .{ }^{46}\right.$

De outro lado, conservadores buscaram forças não do passado temporal, mas do passado espiritual do povo, convergindo para visões organicistas da sociedade política ou do Estado:

Historicismo e organicismo são 'noções combatentes aliadas' contra dois núcleos essenciais do pensamento político-constitucional do século XVIII: à razão, se opõe a história; aos indivíduos, se opõem os organismos vivos. [...].

0 que especialmente importa é que, para os conservadores, o sujeito político é o organismo social e a história é sua lei de vida, assim como para os revolucionários o sujeito são os indivíduos reunidos em sociedade e sua lei é a Constituição. $\left[\ldots . .{ }^{47}\right.$

Segundo o autor ${ }^{48}$, a identificação da ciência do direito com a história do direito leva a um positivismo historicista paralelo ao positivismo legalista, pois em ambos o direito é servil, acrítico, declaratório, diante uma autoridade soberana posta, seja o legislador ou a história. Ao excluir a discussão sobre os fundamentos, priva-se a ciência constitucional da possibilidade de desenvolver uma função crítica e criativa. Por isso uma ciência constitucional não pode se resumir a uma ciência da Constituição, mas ser também a ciência das condições da Constituição. Quando se interessa pelas premissas, sem uma força soberana, legislativa ou histórica, a Constituição deixa de ser dado positivo e se converte em problema, "um objetivo fundanteconstrutivo que a ciência constitucional deve perseguir de acordo com a estrutura da situação constitucional concreta e as exigências que emanam dela" ${ }^{49}$.

$O$ autor relata que ao final do século XIX já se defendia um método misto, 'ideal e real', unindo filosofia e razão atinentes ao elemento ideal, e história, sociologia e economia

\footnotetext{
${ }^{46}$ Ibid., p. 55, tradução nossa: "[...]. toda la ideologia constitucional de la Revolución, desde el punto de vista de las 'fuerzas constituyentes', está contenida en su posición ahistórica o anti-histórica. Una visión de la constitución sin passado, ya que nace de una fractura, y sin futuro o, mejor, com un futuro todo concentrado o contraído em la aceleración representada por el acto constituyente, no puede sino descuidar o combatir la historia como fator constituyente. [...]."

${ }^{47}$ ZAGREBELSKY, Gustavo. Historia y constitución. Miguel Carbonell (Trad.). Torino: Minima Trotta, 1996, p. 60-62, tradução nossa: “Historicismo y organicismo son 'nociones combatientes aliadas' contra los núcleos esenciales del pensamento político-constitucional del siglo XVIII: a la razón, se opone la historia; a los indivíduos, se oponen los organismos vivos. [...]". "Lo que importa especialmente es que, para los conservadores, el sujeto político es el organismo social y la historia es su ley de vida, así como para los revolucionários el sujeto son los indivíduos reunidos en sociedade y su ley es la constitución. [...]"

48 Ibid., p. 73-74.

49 Ibid., p. 74. Tradução nossa: "um objetivo fundante-constructivo que la ciencia constitucional debe perseguir de acuerdo com la estrutura de la situación constitucional concreta y las exigências que emanan de ella".
} 
DIREITOS FUNDAMENTAIS NO BRASIL: UMA HISTÓRIA DE INEFETIVIDADE

DIEGO NASSIF DA SILVA VLADIMIR BREGA FILHO

pertinentes ao elemento real: um método que une a consideração pela experiência da tradição e a abertura pela inovação racional, correspondendo a um ethos político moderado:

A história, aqui, deixa de ser uma essa autoridade tirânica e exclusiva que o historicismo concebia. A filogênese das instituições constitucionais não exclui uma razoável intervenção da vontade e dos projetos dos homens, que podem encontrar lugar nas cartas constitucionais. Por uma parte, reconhecem a Constituição tradicional, por outra a inovam. ${ }^{50}$

A substituição da soberania do legislador pela supremacia da Constituição transformou-a de 'ato criativo' em 'texto de resposta', e nossa posição diante dela, de 'obedientes' para 'interrogantes', na busca de respostas a casos difíceis. Disso, a Constituição não é "ponto de partida de que irradia uma força unívoca e incondicionada" senão "um campo de gravitação, um ponto de chegada e de convergência do pluralismo político e social" ${ }^{51}$ :

Esta quebra afeta a noção de positividade da Constituição. A Constituição revolucionária se considera positiva porque era criada de uma vez por todas com um ato de vontade inicial, limitado no tempo e irrepetível. Pelo contrário, a Constituição do pluralismo contemporâneo se pode considerar positiva enquanto é recriada continuamente pelo concurso de múltiplas vontades que [...] a definem continuamente em seu alcance histórico concreto. Em resumo: a positividade da Constituição revolucionária era a priori; a da Constituição pluralista é a posteriori. ${ }^{52}$

Concluindo, pois, que uma ciência do direito constitucional não pode abdicar de um papel autonomamente construtivo, Zagrebelsky elucida a destruição do vínculo 'hereditário' com os pais fundadores quando há a ruptura da vida constitucional em relação à constituinte. A necessidade de novos valores políticos e novas identidades conduz à morte simbólica dos pais através da deslegitimação de sua autoridade e, com ela, da própria Constituição que já não

\footnotetext{
${ }^{50}$ ZAGREBELSKY, Gustavo. Historia y constitución. Miguel Carbonell (Trad.). Torino: Minima Trotta, 1996, p. 77. Tradução nossa: "La historia, aqui, deja de ser esa autoridade tirânica y exclusiva que el historicismo concebia. La filogénesis de las instituiciones constitucionales no excluye una razonable intervención de la voluntad y de los proyectos de los hombres, que pueden encontrar sitio en las Cartas constitucionales. Por una parte reconocen la constitución tradicional, por otra, la innovan."

${ }^{51}$ Ibid., p. 81-82. Tradução nossa: "punto de partida del que irradia uma fuerza unívoca e incondicionada [...] más bien em un campo de gravitación, un punto de llegada y de convergência del pluralismo político y social."

52 Ibid., p. 82. Tradução nossa: "Esta quebra afecta a la noción de positividade de la constitución. La constitución revolucionaria se consideraba positiva porque era creada de una vez por todas com un acto de voluntad inicial, limitado en el tempo e irrepetible. Por el contrario, la constitución del pluralismo contemporáneo se puede considerar positiva en cuando que es recreada continuamente por el concurso de múltiples voluntades que [...] la redefinen continuamente en su alcance histórico-concreto. En resumen: la positividade de la constitución revolucionaria era a priori; la de la constitución pluralista es a posteriori."
} 
DIREITOS FUNDAMENTAIS NO BRASIL: UMA HISTÓRIA DE INEFETIVIDADE

DIEGO NASSIF DA SILVA VLADIMIR BREGA FILHO

figura mais como a priori da vida política e social. Isto impõe uma conversão: “já não é da Constituição de onde se pode olhar a realidade, senão que é da realidade de onde se deve olhar a Constituição" ${ }^{53}$ :

A legitimidade da Constituição então não depende da legitimidade de quem a fez e falou por meio dela, senão da capacidade de oferecer respostas adequadas ao nosso tempo ou, mais precisamente, da capacidade da ciência constitucional de buscar e encontrar essas respostas na Constituição. Em resumo: a Constituição não diz, somos nós que a fazemos dizer. ${ }^{54}$

Nesse passo, há marcos identificáveis por meio de normas-princípio, que tanto declaram raízes culturais quanto indicam direções, oferecendo um ponto de referência no passado e orientação para o futuro, sendo, ao mesmo tempo, fatores de conservação e de inovação, de "uma inovação que consiste na realização, sempre mais completa e adequada às circunstâncias do presente, do gérmen primordial que constitui o princípio”. E conclui: “em uma Constituição baseada em princípios, a interpretação é o ato que relaciona um passado constitucional assumido como valor e um futuro que se oferece a nós como problema para resolver na continuidade" 55 .

Concebe-se, assim, uma Constituição cuja legitimidade reside na capacidade de refletir a própria sociedade, e, por isso, um poder atual, plural e que primeiro converge para um centro de legitimação axiológico (de um passado) e teleológico (para um futuro) sobre o qual gravita, para então depois reverberar sobre a sociedade. À medida que este instrumento não reflete mais os valores e fins a serem realizados pela sociedade (sempre atual), ou seja, a partir do ponto que não serve mais para oferecer respostas às questões que a sociedade hoje the faz, surge a oportunidade de uma superação ou ruptura.

É de se observar, porém, que uma Constituição bem elaborada capta a natureza dúctil do direito e, assim, procura também dotar-se de uma instrumentalidade capaz de garantir que

\footnotetext{
53 Ibid., p. 87. Tradução nossa: "ya no es desde la constitución desde donde se puede mirar la realidade, sino que es desde la realidade desde donde se debe mirar la constitución."

${ }^{54}$ ZAGREBELSKY, Gustavo. Historia y constitución. Miguel Carbonell (Trad.). Torino: Minima Trotta, 1996, p. 88. Tradução nossa: "La legitimidade de la constitución depende entonces no de la legitimidade de quien la há hecho y há hablado por medio de ella, sino de la capacidade de ofrecer respuestas adecuadas a nuestro tiempo o, más precisamente, de la capacidade de la ciência constitucional de buscar y encontrar essas respuestas en la constitución. En resumen: la constitución no disse, somos nosotros los que la hacemos decir."

55 Ibid., p. 89-90. Tradução nossa: "una innovación que consiste en la realización siempre más completa y adecuada a las circunstancias del presente del germen primigênio que constituye el principio". "En una constitución basada en princípios, la interpetación es e lacto que relaciona un pasado constitucional assumido como valor y un futuro que se nos ofrece como problema para resolver en la continuidad."
} 


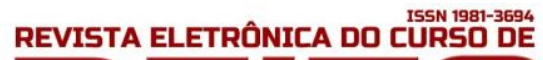

DIREITOS FUNDAMENTAIS NO BRASIL: UMA HISTÓRIA DE INEFETIVIDADE

não se quebrará como cristal ao mínimo choque com a realidade. Bem por isso Zagrebelsky observa que o núcleo de constitucionalidade é formado por princípios, que, numa metáfora livre, tanto servem de trave axiológica fixada no passado, como farol que fixa e ilumina objetivos a serem realizados cada vez mais plenamente em um futuro.

\section{INEFETIVIDADE DOS DIREITOS FUNDAMENTAIS E JURISDIÇÃO CONSTITUCIONAL: UMA HISTÓRIA DO DEVIR}

Se a mão morta dos pais fundadores não é a tirana que nos priva do poder de fazer das constituições um novo espelho de nossa sociedade, o processo histórico, como autoridade imanente ao homem e suas obras, não é escusável. Passado, presente e futuro convivem quando o homem se põe em movimento. Neste ponto, a mais bela democracia e a mais terrível tirania, enquanto constituições ideais, se equivalem pois visam por fim a qualquer esperança de se furtar às circunstâncias, de inovar, enfim, de dar vazão à condição humana da natalidade ${ }^{56}$-que coloca o imponderável como uma variável perene, inerente à própria humanidade.

Os obstáculos: colocados um após o outro dão a dimensão do nosso caminhar, pondo-nos a imaginar: qual é o próximo? A inexistência de um novo 'obstáculo' (desafio) ou a impossibilidade de sua verificação é o que parece mover as alegações acerca do 'fim da história' -enquanto referencial humano ${ }^{57}$.

Nessa perspectiva, a própria noção de civilização ou desenvolvimento torna-se problemática, pois, reconhecendo que os direitos humanos surgiram de condições históricas objetivas, tendo sua positivação e garantia derivado de situações de negação e ameaça, em teoria, seria juridicamente mais avançada a sociedade quanto mais negados e ameaçados tenham sido os (proto)direitos. E isso não é verdade. Porém, aceitar que povos e culturas diferentes encontram-se em 'momentos' jurídicos diferentes importa admitir não só que as condições histórico-materiais condicionam o grau ou o tipo de efetivação de direitos em dado momento e lugar mas a própria possibilidade de percepção desses direitos. Ou seja, a questão

\footnotetext{
${ }^{56}$ ARENDT, Hannah. A condição humana. Roberto Raposo (Trad.). Adriano Correia (Rev.téc.). 11. ed. rev. Rio de Janeiro: Forense Universitária, 2010, passim.

${ }^{57}$ No intuito de furtar-se à sua própria futilidade cronológica (mortalidade) as pessoas buscam perenizarse através da das suas obras no mundo, condição de mundaneidade também abordada por Arendt (Ibid., passim).
} 
DIREITOS FUNDAMENTAIS NO BRASIL: UMA HISTÓRIA DE INEFETIVIDADE

DIEGO NASSIF DA SILVA VLADIMIR BREGA FILHO

entre universalidade (ideal) e historicidade (material) dos direitos humanos e fundamentais não são necessariamente excludentes, mas sim complementares sob o viés dinâmico.

Nessa linha de raciocínio, a negação e ameaça dos direitos não precisa ser efetiva em dado tempo e lugar de uma sociedade para que se possibilite sua percepção, garantia e efetivação, bastando que a sensibilidade e acuidade dos seus teóricos tomem conhecimento deste outro momento ou dimensão. A Constituição é um desses momentos em que se olha ao longo e além.

Retomando a comparação, se a relação entre democracia política e democracia social encontra avanços e retrocessos, a relação entre percepção de direitos fundamentais e sua efetivação não admite retrocessos sob a ótica jurídico-institucional. É que, desenvolvido a reboque dos direitos humanos, o constitucionalismo encontrou na petrificação desses direitos (fundamentais) o seu substrato estruturante-legitimador. Assim, negar aos direitos fundamentais equivaleria a negar as próprias razões de ser da Constituição e do Estado.

Embora estabelecida ad eternum, a petrificação de direitos não é uma tentativa de furtar-se ao processo histórico, pois aí a imutabilidade não está no consequente constitucional, mas no seu antecedente, no pressuposto que the confere estabilidade. Isso leva a discussão para outro âmbito: o hermenêutico.

Com efeito, elevados os direitos fundamentais ao plano principiológico, a Constituição ganhou ductilidade mediante o exercício hermenêutico, que, lembra Eros Grau, "não é uma atividade de conhecimento, mas sim construtiva, portanto decisional, embora não discricionária" ${ }^{58}$.

Retomando, pois, o conflito entre os pais fundadores e o impulso democrático, agora no âmbito propriamente jurisdicional, Appio observa:

[...] se de um lado os juízes são tencionados pela dificuldade contramajoritária, levando-os contra importantes indagações acerca de sua legitimidade na democracia, de outro lado o 'problema da mão-morta' os incentiva a atualizar a Constituição, abandonando a intensão originalista. A geração atual não quer ser governada por seus antepassados, pois acredita que suas principais necessidades mudaram ao longo dos anos. [...]. [...] em uma sociedade contemporânea, marcada pela velocidade dos acontecimentos políticos e transitoriedade de valores, uma interpretação rígida da Constituição pode asfixiá-la em vez de preservar seus fundamentos. Os juízes -e não o Congresso- têm a responsabilidade de atualizar a Constituição, de maneira que vocábulos como vida, liberdade e dignidade humana devem ser interpretados em um contexto contemporâneo e real e não hipotético e ultrapassado. Os juízes são

\footnotetext{
${ }^{58}$ GRAU, Eros Roberto. Interpretação/aplicação do direito. 2. ed. São Paulo: Malheiros, 2003, p. 62.
} 
DIREITOS FUNDAMENTAIS NO BRASIL: UMA HISTÓRIA DE INEFETIVIDADE

DIEGO NASSIF DA SILVA VLADIMIR BREGA FILHO

constantemente tensionados entre preservar as conquistas do passado, sem contudo inviabilizar o futuro dos demais cidadãos. É paradoxal perceber como a Constituição expressa o desejo de seus autores de perenizar determinados valores e direitos, sem abdicar de um modelo de representação popular. ${ }^{59}$

Outrossim, se a jurisdição constitucional representou a grande invenção contramajoritária na garantia dos direitos fundamentais e, assim, da própria democracia ${ }^{60}$, de outro, reconhecendo na norma jurídica não só uma dimensão de validade legal-formal mas também de legitimidade ético-política ${ }^{61}$, passou a cuidar de mais, mais extensos e mais específicos conteúdos constitucionais impostos, atingindo o ponto de possibilitar a provocação do Judiciário a exercer uma função socioterapêutica na proteção dos direitos fundamentais ${ }^{62}$.

Embora haja esforço para que os juízes e tribunais se valham cada vez mais de instrumentos de participação popular como o amicus curiae e audiências públicas, não se pode confundir isso com a transformação do Judiciário em um órgão de atuação política - o que, de maneira alguma, implica apartar-lhe dos conteúdos sociais, éticos e políticos inerentes ao Direito. O Judiciário não deve ser um 'poder' a ser contraposto na luta pelo poder, mas o principal 'freio' ${ }^{63}$ institucional, garantidor da ordem constitucional, tanto sob o aspecto formalestrutural, quanto material-conteudístico.

Ora, se as constituições são frutos de momentos de extraordinária coesão social em torno de valores e objetivos fundantes, sua interpretação pelas pessoas que se seguem não deve ser imbuída de menor expressão. Daí a legitimidade da atuação jurisdicional deve estar vinculada à sua racionalidade e à sua capacidade de justificação ${ }^{64}$, podendo-se dizer que a autoridade/legitimidade dos tribunais se mede pela respeitabilidade (e não popularidade) de suas decisões - as quais, aliás, devem ser sempre submetidas à mais incisiva, acurada e constante vigilância da opinião pública, dos demais poderes constituídos, dos órgãos e cortes internacionais, enfim, de toda uma sociedade de intérpretes da Constituição ${ }^{65}$.

\footnotetext{
${ }^{59}$ APPIO, Eduardo. Direito das minorias. São Paulo: Revista dos Tribunais, 2008, p. 281

${ }^{60}$ CAMBI, Eduardo. Neoconstitucionalismo e neoprocessualismo: direitos fundamentais, políticas públicas e protagonismo judiciário. São Paulo: Revista dos Tribunais, 2010. p. 205. Ver também: NOVAIS, Jorge Reis. Direitos fundamentais: trunfos contra a maioria. Coimbra: Coimbra Ed., 2006, passim.

${ }^{61}$ CANOTILHO, José Joaquim Gomes. Direito constitucional e teoria da constituição. 3. ed. Coimbra: Almedina, 1998. p. 93-94 e 96.

${ }^{62}$ Cf. FERRAZ JUNIOR, Tercio Sampaio. Direito constitucional. Barueri: Manole, 2007.p. 406.

${ }^{63}$ WOOTTON, David. Liberty, metaphor, and mechanism: 'checks and balance' and the origins of modern constitutionalism. In: Liberty and American experience in the Eighteenth Century. Indianapolis: Liberty Found, 2006.

${ }^{64}$ CAMBI, Eduardo. Op. cit., p. 199.

65 "Todo aquele que vive no contexto regulado por uma norma e que vive com este contexto é, indireta ou, até mesmo diretamente, um intérprete dessa norma. 0 destinatário da norma é participante ativo,
} 
DIREITOS FUNDAMENTAIS NO BRASIL: UMA HISTÓRIA DE INEFETIVIDADE

DIEGO NASSIF DA SILVA VLADIMIR BREGA FILHO

Embora pareça que entre a disposição formal de direitos e sua efetivação o elemento político se coloque de modo inescusável - em atenção ao princípio democrático -, saliente-se que jurisdição e Constituição já não ficam, caminham junto. A Constituição do pluralismo é recriada continuamente e suas palavras não são vazias. Já não vigora a Constituição Folha de Papel de Lassalle, mero retrato formal dos fatores reais de poder ${ }^{66}$, mas vige sim a Constituição dotada de força normativa, acerca da qual Hesse escreveu:

[...] pode-se afirmar que a Constituição converter-se-á em força ativa se fizerem-se presentes, na consciência geral - particularmente, na consciência dos principais responsáveis pela ordem constitucional -, não só a vontade de poder ('Wille zur Macht'), mas também a vontade de Constituição ('Wille sur Verfassung').

Essa vontade de Constituição origina-se de três vertentes diversas. Baseia-se na compreensão da necessidade e do valor de uma ordem normativa inquebrantável, que proteja o Estado contra o arbítrio desmedido e disforme. Reside, igualmente, na compreensão de que essa ordem constituída é mais do que uma ordem legitimada pelos fatos (e que, por isso, necessita de estar em constante processo de legitimação). Assenta-se também na consciência de que, ao contrário do que se dá com uma lei do pensamento, essa ordem não logra ser eficaz sem o concurso da vontade humana. Essa ordem adquire e mantém sua vigência através de atos de vontade. Essa vontade tem consequência porque a vida do Estado, tal como a vida humana, não está abandonada à ação surda de forças aparentemente inelutáveis. Ao contrário, todo nós estamos permanentemente convocados a dar conformação à vida do Estado [...]. ${ }^{67}$

A relação das pessoas de seu tempo com as instituições que possuem e criam é um confronto com o passado sempre com vistas a um futuro. Há tempos em que as instituições parecem corromper as pessoas, há tempos em que as pessoas é que parecem corrompê-las, mas, em verdade, conservação e revolução convivem num só tempo. Dar vida à Constituição e, assim, aos direitos fundamentais é tarefa cotidiana, é uma responsabilidade humana e cívica, devendose reconhecer que aos direitos de humanidade, ou de cidadania, concorrem igualmente deveres de humanidade, ou de cidadania.

muito mais ativo do que se pode supor tradicionalmente, do processo hermenêutico. Como não são apenas os intérpretes jurídicos da Constituição que vivem a norma, não detêm eles o monopólio da interpretação da Constituição." (HÄBERLE, Peter. Hermenêutica constitucional: a sociedade aberta dos intérpretes da constituição: contribuição para a interpretação pluralista e 'procedimental' da constituição. Gilmar Ferreira Mendes (Trad.). Porto Alegre: Sérgio Antonio Fabris Editor, 1997, p. 15)..

66 "Juntam-se esses fatores reais do poder, escrevemo-los em uma folha de papel, dá-se-lhes expressão escrita e a partir desse momento, incorporados a um papel, não são simples fatores reais do poder, mas sim verdadeiro direito, nas instituições jurídicas e quem atentar contra eles atenta contra a lei, e por conseguinte é punido." (LASSALE, Ferdinand. Que é uma constituição? Walter Stönner (Trad.). São Paulo: Edições e Publicações Brasil, 1933).

67 HESSE, Konrad. A força normativa da constituição. Gilmar Ferreira Mendes (Trad.). Porto Alegre: Sérgio Antonio Fabris Editor, 1991, p. 19-20. 
As constituições brasileiras são, assim, retratos de uma sociedade em movimento - quer para mudar, quer para manter tudo como está. O fato é que a cada passo, novos horizontes descortinam-se revelando novos desafios ou novos aspectos dos mesmos desafios. Daí que, se a apaixonada defesa de 'direitos humanos para humanos direitos' fere de morte a própria lógica dos conceitos envolvidos, de outro cria a oportunidade para a reconstrução desses direitos em bases cada vez mais sólidas e atuais. Assim, tal qual Prometeu - defensor da humanidade na mitologia grega e condenado pelos deuses a ter seu fígado devorado por uma águia todos os dias pela eternidade -, a sociedade brasileira, enquanto uma sociedade dos intérpretes da Constituição, tem renovado dia a dia o desafio de reafirmar os direitos fundamentais.

Quanto a esta constante luta - que Ihering $^{68}$ e Couture $^{69}$ não nos deixam esquecer -, relembrando a condição humana da natalidade pela qual o imponderável se faz permanentemente presente na atividade/criação humana, inclusive no campo hermenêutico, bem como considerando que nos processos democrático e de percepção e efetivação dos direitos essa intervenção pode ser cíclica ou anticíclica (para não usar os valorativos 'pró' e 'contra'), merecem atenção as considerações de Reinéro para quem: “A espécie humana parece ter libertado tudo, ou quase tudo do que havia de mal na Caixa de Pandora, deixando para o 'final' apenas a esperança. Palavra tão emblemática quanto apocalíptica" ${ }^{70}$.

\section{CONCLUSÃO}

Ao final do presente estudo tem-se claro que não se pode imaginar a consecução dos direitos fundamentais em outro ambiente que não o democrático e não se pode conceber uma democracia que não tenha por fim último a realização daquele conjunto de todas as condições de vida social que consintam e favoreçam o desenvolvimento integral da pessoa humana - cuja garantia e efetivação a todos passa pela proclamação dos direitos fundamentais na Constituição.

Tem-se também que as conquistas da Constituição Cidadã relativizaram-se, porém, não por força de equívocos ou fracassos, mas porque é da essência das leis e normas - como toda

68 IHERING, Rudolf von. A luta pelo direito. Pietro Nassetti (Trad.). São Paulo: Martin Claret, 2011, passim.

${ }_{69}$ COUTURE, Eduardo. Os mandamentos do Advogado. Ovídio Baptista da Silva (Trad.). Porto Alegre: Sérgio Antonio Fabris Editor, 1999, passim.

${ }^{70}$ LÉRIAS, Reinéro Antonio. Ética, moral, ciência e direitos humanos. In: Argumenta: Revista do Programa de Mestrado em Ciência Jurídica, da Universidade Estadual do Norte do Paraná - UENP, n. 7, jan./jul., Jacarezinho: UENP, 2008, p. 112. 
obra humana - a historicidade. Achando feio tudo que não é espelho as sociedades têm a necessidade de negar o passado e sonhar com um novo futuro. Unindo-se tal desejo ao próprio desenrolar do processo histórico, cada vez mais acelerado, tem-se exigido igualmente a constante releitura e reforma da Constituição como reflexo da própria mutação da sociedade e seus valores.

O desarranjo ético e institucional que se apresenta tão grave hoje no Brasil também se mostra, ao menos em parte, resultado desse processo que, de tempos em tempos, evidencia a ascensão e queda de mecanismos de poder e ideologia, colocando em pauta os próprios rumos a serem seguidos. Nesses momentos não se deve deixar abalar os direitos conquistados, nem abrir mão de um legado histórico em busca de total revolução. Também não se deve deixar intimidar pelos desafios da contemporaneidade, negando avanços à democracia política e social.

Por outro lado, se quase 200 anos e 7 constituições depois pouco ou quase nada mudou no país, talvez esteja no intérprete e não nas constituições a mudança que se busca. Com efeito, se uma Constituição tão jovem como a de 1988 supostamente perdeu sua capacidade de iluminar os caminhos da sociedade brasileira tornando-se um conto de fadas ou, pior, um pedaço de papel não se pode afastar a hipótese de que seus intérpretes o permitiram, dado que não é a Constituição que diz, nós é que a fazemos dizer.

Aparentemente ainda hoje não nos atentamos para todas as conquistas representadas pela Constituição de 1988; é possível também que ela não reflita, ou nunca tenha refletido, todos os aprofundamentos e nuances que a realidade brasileira exige. 0 mais provável, porém, é que ambos os fenômenos ocorram ao mesmo tempo. Fato é que a luta pelos direitos humanos dos 'humanos direitos' - seja lá o sentido que se dê à expressão - per si não é inválida, desde que não pressuponha negá-los aos demais cidadãos. A luta pela efetivação dos direitos fundamentais é sempre legítima e pode até dispor de diferentes caminhos e vir a sofrer revezes, mas jamais admitirá retrocessos, sobretudo no plano institucional.

Nesse passo, uma jurisdição constitucional ativa, sensível às transformações sociedade, aberta ao debate, ao diálogo e pronta à prestação de contas aos demais intérpretes da Constituição é essencial não apenas para fazer florescer uma democracia participativa, regime de garantia geral à efetivação dos direitos fundamentais, mas também revigorar a própria Constituição em seu caráter instrumental, pois a cada esquina da história os brasileiros, assim como dos demais povos, encontrar-se-ão frente a frente com os fantasmas de seu passado, com as incertezas do futuro e com um duro retrato de sua realidade, reveladoramente humana. 


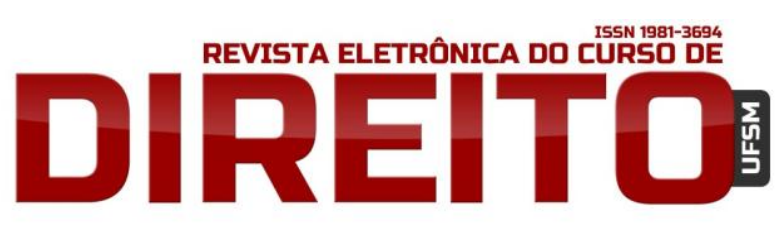

DIREITOS FUNDAMENTAIS NO BRASIL: UMA HISTÓRIA DE INEFETIVIDADE

\section{REFERÊNCIAS}

APPIO, Eduardo. Direito das minorias. São Paulo: Revista dos Tribunais, 2008.

ARENDT, Hannah. A condição humana. Roberto Raposo (Trad.). Adriano Correia (Rev.téc.). 11. ed. rev. Rio de Janeiro: Forense Universitária, 2010.

BOBBIO, Norberto. A era dos direitos. Carlos Nelson Coutinho (Trad.). 13. tir. Rio de Janeiro: Campus, 1992.

1997.

. Igualdade e liberdade. 3. ed. Carlos Nelson Coutinho (Trad.). Rio de Janeiro: Ediouro,

. O futuro da democracia. 8. ed. rev. ampl. Marco Aurélio Nogueira (Trad.). São Paulo: Paz e Terra, 2002.

- Teoria geral da política: a filosofia política e as lições dos clássicos. Michelangelo Bovero (Org.); Daniela Beccaccia Versiani (Trad.). 5. tir. Rio de Janeiro: Campus, 2000.

BONAVIDES, Paulo. Curso de direito constitucional. 10. ed. rev. atual. São Paulo: Malheiros, 2000.

BONAVIDES, Paulo; ANDRADE, Paes de. História constitucional do Brasil. 3. ed., Rio de Janeiro: Paz e terra, 1991.

CAMBI, Eduardo. Neoconstitucionalismo e neoprocessualismo: direitos fundamentais, políticas públicas e protagonismo judiciário. São Paulo: Revista dos Tribunais, 2010.

CANOTILHO, José Joaquim Gomes. Direito constitucional e teoria da constituição. 3. ed. Coimbra: Almedina, 1998.

COMPARATO, Fábio Konder. A afirmação histórica dos direitos humanos. 3. ed. rev. ampl. 2. tir. São Paulo: Saraiva, 2004.

COUTURE, Eduardo. Os mandamentos do Advogado. Ovídio Baptista da Silva (Trad.). Porto Alegre: Sérgio Antonio Fabris Editor, 1999.

DECLARAÇÃo de direitos do homem e do cidadão. França, 26 ago. 1789. São Paulo: USP.Disponível em: <http://www.direitoshumanos.usp.br/index.php/Documentos-anteriores\%C3\%A0-cria\%C3\%A7\%C3\%A3o-da-Sociedade-das-Na\%C3\%A7\%C3\%B5es-at\%C3\%A9-1919/declaracaode-direitos-do-homem-e-do-cidadao-1789.html>. Acesso em: 04 jan. 2016.

FERRAZ JUNIOR, Tercio Sampaio. Direito constitucional. Baueri: Manole, 2007.

FERREIRA FILHO, Manoel Gonçalves. A democracia possível. São Paulo: Saraiva, 1972.

. Democracia no limiar do século XXI. São Paulo: Saraiva, 2001. 
FUNDAÇÃO GETÚLIO VARGAS. Dicionário Histórico Biográfico Brasileiro pós 1930. 2. ed. Rio de Janeiro: FGV, 2001. Disponível em:

<https://cpdoc.fgv.br/producao/dossies/AEraVargas1/biografias/antonio_carlos_ribeiro_de_and rada>. Acesso em: 04 jan. 2016.

GUIMARÃES, Ylves José de Miranda. Comentários à Constituição: direitos e garantias individuais e coletivas. Rio de Janeiro: Forense, 1989.

GRAU, Eros Roberto. Interpretação/aplicação do direito. 2. ed. São Paulo: Malheiros, 2003.

HÄBERLE, Peter. Hermenêutica constitucional: a sociedade aberta dos intérpretes da Constituição: contribuição para a interpretação pluralista e 'procedimental' da Constituição. Gilmar Ferreira Mendes (Trad.). Porto Alegre: Sérgio Antonio Fabris Editor, 1997.

HESSE, Konrad. A força normativa da constituição. Gilmar Ferreira Mendes (Trad.). Porto Alegre: Sérgio Antonio Fabris Editor, 1991.

MORRIS, Clarence. Os grandes filósofos do direito. Reinaldo Guarany (Trad.). São Paulo: Martins Fontes, 2002.

IHERING, Rudolf von. A luta pelo direito. Pietro Nassetti (Trad.). São Paulo: Martin Claret, 2011.

JOÃO XXIII. Encíclica pacem in terris, Roma: Vaticano, 11 abr.1963, Item 58. Disponível em: <http://w2.vatican.va/content/john-xxiii/pt/encyclicals/documents/hf_jxxiii_enc_11041963_pacem.html\#_ftn34>. Acesso em: 04 jan. 2016.

Encíclica mater et magistra. Roma: Vaticano, 15 maio 1961, item 65. Disponível em: <http://w2.vatican.va/content/john-xxiii/pt/encyclicals/documents/hf_jxxiii_enc_15051961_mater.html>. Acesso em: 04 jan. 2016.

LAFER, Celso. A reconstrução dos direitos humanos: a contribuição de Hannah Arendt. In: Revista Estudos Avançados. v. 11, n. 30, p. 55-65. São Paulo: Instituto de Estudos Avançados da Universidade de São Paulo, maio-ago.,1997.

LASSALLE, Ferdinand. Que é uma constituição? Walter Stönner (Trad.). São Paulo: Edições e Publicações Brasil, 1933.

LÉRIAS, Reinéro Antonio. As constituições brasileiras: direitos fundamentais e cidadania. In: ALVES, Fernando de Brito; CAMBI, Eduardo; KLOCK, Andrea Bulgakov (Org.). Direitos fundamentais revisitados, 1. ed, 1. reimp. Curitiba: Juruá, 2009.

. Ética, moral, ciência e direitos humanos. In: Argumenta: Revista do Programa de Mestrado em Ciência Jurídica, da Universidade Estadual do Norte do Paraná - UENP, n. 7, jan./jul., Jacarezinho: UENP, 2008.

. O processo penal e os direitos humanos sob os grilhões de nosso passado inquisitorial. In: Argumenta: Revista do Programa de Mestrado em Ciência Jurídica, da Universidade Estadual do Norte do Paraná - UENP, n. 16, jan./jul., Jacarezinho: UENP, 2012. 


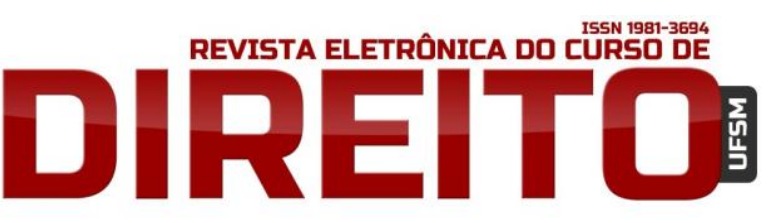

DIREITOS FUNDAMENTAIS NO BRASIL: UMA HISTÓRIA DE INEFETIVIDADE

MACPHERSON, Crawford Brough. A democracia liberal: origens e evolução. Nathanael C. Caixeiro (Trad.). Rio de Janeiro: Zahar, 1978.

NOVAIS, Jorge Reis. Direitos fundamentais: trunfos contra a maioria. Coimbra: Coimbra Ed., 2006.

ORGANIZAÇÃO DAS NAÇÕES UNIDAS - ONU. Declaração universal dos direitos humanos. Paris: ONU, 1948. Disponível em <http://www.ohchr.org/EN/UDHR/Documents/UDHR_Translations/por.pdf>. Acesso em: 04 jan. 2016.

ROUSSEAU, Jean-Jacques. Rousseau: vida e obra. Os pensadores. São Paulo: Abril Cultural, 1983.

SILVA, José Afonso da. Curso de direito constitucional positivo. 17. ed. rev. atual. São Paulo: Malheiros, 2000.

UNIVERSITY OF GRONINGEN. American History: from revolution to reconstruction and beyond The Letters of Thomas Jefferson 1743-1826: to James Madison Paris, Sep. 6, 1789. Disponível em: <http://www.let.rug.nl/usa/presidents/thomas-jefferson/letters-of-thomas-

jefferson/jefl81.php>. Acesso em: 04 jan. 2016.

ZAGREBELSKY, Gustavo. Historia y constitución. Miguel Carbonell (Trad.). Torino: Minima Trotta, 1996.

WOOTTON, David. Liberty, metaphor, and mechanism: 'checks and balance' and the origins of modern constitutionalism. In: Liberty and American experience in the Eighteenth Century. Indianapolis: Liberty Found, 2006. 